\title{
Estimating Salinity of Soils from Northwest of Egypt using Different Soil-to- Water Ratio Extracts
}

\author{
Ramzy M.R. Hedia
}

\begin{abstract}
Saturated soil paste extracts and different soil to water ratios are commonly used in soil salinity studies and field remediation of salt-affected soils. This experimental study was carried out to assess the possibility of estimating electrical conductivity and soluble ions concentrations of saturated soil paste extracts from 1:1, 1:2.5 and 1:5 soil to water ratios. Twenty-five undisturbed surface soil samples were collected to represent sandy, calcareous and clay soils commonly occur in the Northwest of Egypt. Electrical conductivity (EC) and major soluble ions concentrations were measured. Soil specific and combined regression equations and coefficients of determination of saturated soil paste $E C$ and analytes versus $1: 1,1: 2.5$ and $1: 5$ soil to water ratios were evaluated. Estimation of saturated soil paste $\mathrm{EC}$ and other analytes from these soil to water ratios was successful with high correlation except for $\mathrm{K}$ and $\mathrm{Ca}$ ions in sandy and calcareous soil, respectively. Slopes of regression lines in proximity of 2,4 and 7.5 for the $1: 1$, 1:2.5 and 1:5 soil to water ratios, respectively reflect the dilution effect of readily soluble salts. The use of these regression equations to estimate the saturated soil paste EC and other analytes has potential benefits of minimizing labor, time and costs required for saturated soil paste extract preparation. Soil specific regression equations are recommended for more precise estimation of saturated soil paste attributes.
\end{abstract}

Keywords: Salinity, Soil to water ratios, Extracts, Electrical conductivity, soluble ions concentrations.

\section{INTRODUCTION}

Soil salinity represents the concentration of dissolved mineral salts in soil and it is considered one of the most important environmental factor that limits the yield of agricultural crops. Cultivated crops respond tremendously different to increasing soil salinity level where their production is adversely affected (Nassem et al.,2008; Sonmez et al., 2008). Salinization of soils is commonly related to either intrinsic soil properties or environmental conditions. In addition, some agricultural practices such as irrigation water quality, fertilization, lack of or inefficient drainage, seepage.., etc. contribute significantly in soil salinity build up (Pitman and Lauchli, 2002; Shama et al.,2016). Arid and semi-arid regions are known to have extended areas of salt affected soils. Data on the extent and severity of salt affected soils are observational. Though, estimates showed that about 955 million ha of the world are under different categories of salt affected soils (Qadir et al., 2000).

Determination of soil salinity can be conducted by various methods depending on different situations. Measurements can be made on extracts from saturated soil paste, soil to water suspensions of different ratios or in situ soil water samples collected with vacuum extractors, or in soil, using buried porous salinity sensors or using four-electrode probes or remotely by electromagnetic induction techniques (Rhoades and Loveday, 1990).

The EC of the saturated paste extract, $\mathrm{EC}_{\mathrm{SP}}$, is a more meaningful measurement being closer to field water content and can be related to the large amount of published data on plant salt tolerance (Ayers and Westcot, 1989; Shaw, 1994). However, obtaining this saturated past extract encounters difficulties related to sample preparation, time consumption and reproducibility (USDA, 1954). The extraction methods of different soil to water ratios can overcome these difficulties due to the consistency of the amount of water and the objective nature of the method. Despite the differences between the results obtained from soil to water extraction methods, many laboratories started to use it due to its simplicity, reduced monetary and time investment (Franzen, 2003; Zhang et al., 2005). Ion concentrations and electrical conductivities of the extracts of different soil to water ratios are typically lower than those of saturated paste extracts as a result of the increased dilution effect.

According to the USDA (1954), the EC and major ion concentrations obtained from the 1:1 extraction method can be adjusted with conversion factors. These conversion factors were based on soil moisture holding capacities and the theoretical and actual chemical solubility of ions in aqueous systems (USDA, 1954) However, the impacts of other soil properties such as texture, salt concentrations, organic matter content, cation exchange capacity on ion concentrations and EC were not considered. The exclusion of these soil properties in the conversion factors, coupled with the lack of extensive examination of relationships between the two methods and minimal experimental verification, could contribute to imprecise adjustment of 1:1 analyses when applied to a variety of soils (Franzen, 2003;

${ }^{1}$ Soil and Water Sciences Department,

Faculty of Agriculture, Alexandria University, Egypt.

Received July17, 2016, Accepted August 15, 2016 
Zhang et al., 2005). To improve on the original factors, researchers have developed new conversion techniques using experimental data to generate empirical relationships.

EC conversion factors for 1:1 soil extracts were divided into three textural divisions for coarse, medium, and fine (Franzen, 2003). Hogg and Henry (1984) derived conversion factors for EC and individual ionic species. Soil to water extracts of $1: 1,1.2 .5$ and $1: 5$ were also used to obtained regression relationships with soil paste extracts of soil samples having different textures (Ozcan et al., 2006; Sonmez et al., 2008). Even with the reports of highly correlated relationships between these two methods, the observed variations in the values of conversion factors generated by these studies for various soils restricted its generalization (Sonmez et al., 2008). This necessitates further examination and comparison of these extraction methods to generate a more refined adjustment of different soil to water extracts over a wide range of soil conditions. In addition, in soil laboratories, $\mathrm{pH}$ is measured in 1:2.5 soil water suspensions (Jackson, 1967). If suitable conversion coefficients were determined, EC and $\mathrm{pH}$ can both be measured in the same extract allowing to make the two measurements at once.

Therefore, the objective of this study was to assess the regression correlations between the EC and the major cations and anions concentrations in the saturated soil paste extracts versus different soil to water ratios (SW1:1, SW1:2.5 and SW1:5) for three different soil types commonly occur in the Northwest of Egypt.

\section{MATERIALS AND METHODS}

\section{Soil Sampling and Preparation:}

Three different Egyptian soil types that are prevailing in the Northwestern area of Egypt, sandy textured soils (typic xeropsaments, denoted as SANWD), calcareous soils (typic calciorthids or typic gypsiorthids, denoted as CALMD) and lacusrine and alluvial clay soils (typic terrifluvents, denoted as CLYLA) were used in this study. Twenty five surface soil samples $(0-20 \mathrm{~cm})$ were collected for each soil type from different locations to represent various textural classes, soil salinity levels, and cultivated crops existing in the sampled areas. SANWD soil samples were collected from West Nubaria $\left(30^{\circ} 30^{\prime} 34^{\prime \prime} \mathrm{N}, 30^{\circ} 09^{\prime} 18^{\prime \prime}\right.$ E), South El-Tahrir ( $\left.30^{\circ} 15^{\prime} 58^{\prime \prime} \mathrm{N}, 30^{\circ} 36^{\prime} 20^{\prime \prime} \mathrm{E}\right)$ and Wadi El-Natrun $\left(30^{\circ} 25^{\prime} 04^{\prime \prime} \mathrm{N}, 30^{\circ} 19^{\prime} 40^{\prime \prime}\right.$ E) areas. CALMD soil samples were collected from Nubaria $\left(30^{\circ}\right.$ $\left.47^{\prime} 08^{\prime \prime} \mathrm{N}, 2^{\circ} 46^{\prime} 38^{\prime \prime} \mathrm{E}\right)$, El-Hamam (30 $52^{\prime} 35^{\prime \prime} \mathrm{N}, 29^{\circ}$

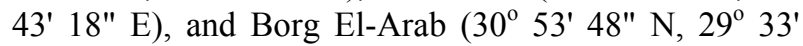
$\left.07^{\prime \prime} \mathrm{E}\right)$ areas. CLYLA soil samples were collected from Abis ( $\left.31^{\circ} 12^{\prime} 43^{\prime \prime} \mathrm{N}, 29^{\circ} 58^{\prime} 56^{\prime \prime} \mathrm{E}\right)$, Kafr El-Dawar ( $31^{\circ}$
09' 09" N, 30 08' 59" E) and Damanhour ( $31^{\circ} 03^{\prime} 29^{\prime \prime}$ $\left.\mathrm{N}, 30^{\circ} 26^{\prime} 49^{\prime \prime} \mathrm{E}\right)$ areas.

Collected soil samples were brought to the laboratory, air dried, sieved $(<2 \mathrm{~mm}$ sieve) and stored for subsequent analysis. Electrical conductivity (EC), $\mathrm{pH}$ and concentrations of major cations and anions in the saturated soil paste extracts of the collected soil samples were determined according to Jackson (1967). Soil texture was determined by the hydrometer method (Day, 1982). Summary statistics of the analysis results are given in Table (1).

\section{Preparation and Analysis of Extracts:}

Preparation of saturated paste extracts (SP) were carried out by adding distilled water to approximately $400 \mathrm{~g}$ soil sample with stirring until it reached saturation and left to equilibrate for $18 \mathrm{~h}$ (Rhoades, 1982). The soil extracts were obtained by vacuum, filtered using Whatman \#42 filter papers and analyzed for major cations $\left(\mathrm{Na}^{+}, \mathrm{K}^{+}, \mathrm{Ca}^{2+}\right.$ and $\left.\mathrm{Mg}^{2+}\right)$ and major anions $\left(\mathrm{Cl}^{-}, \mathrm{CO}_{3}{ }^{2-}\right.$, and $\left.\mathrm{HCO}_{3}{ }^{-}\right)$according to Page et al. (1982). Concentration of $\mathrm{SO}_{4}{ }^{2-}$ was calculated by subtracting the total amounts of anions and cations.

Suspensions of three different soil to water ratios (SW1:1, SW1:2.5 and SW1:5) were prepared. The (SW1:1) soil to water suspension was prepared by adding $100 \mathrm{ml}$ of distilled water to $100 \mathrm{~g}$ of oven-dried soil sample while the (SW1:2.5) and (SW1:5) suspensions were prepared by adding 75 and $150 \mathrm{ml}$ of distilled water to $30 \mathrm{~g}$ of oven-dried soil sample. Soil suspensions were shaken for $1 \mathrm{~min}$ by hand 4 times at 30-minute intervals (Rhoades, 1982). Extracts were obtained from the suspensions by filtration using Whatman \#42 filter paper and analyzed using the same methods as with the saturated soil paste extracts. Triplicates of each soil sample were used in this study for the calculation of mean values.

\section{Statistical Analyses:}

Descriptive statistical analysis of the obtained data was carried out using the Costat software (Costat, 2004) to calculate mean, standard deviation, median, standard error, sample variance kurtosis, skewness, range, minimum, maximum and 95\% confidence level. Regression analysis was also conducted for measured $\mathrm{EC}_{\mathrm{sp}}$ and major cations and anions concentrations in saturated soil paste extracts versus those measured in SW1:1, SW1:2.5 and SW1:5 extracts. Regression equations were derived with and without intercepts. Regression slopes and coefficients of determination $\left(\mathrm{r}^{2}\right)$ were used to evaluate the generated regression relationships in this study. 


\section{RESULTS AND DISCUSSIONS}

The main characteristics of the soils studied revealed that the highest ion concentrations measured in soil paste extracts were $\mathrm{Cl}$ and $\mathrm{Na}$ ions (Table 1). The descriptive statistics for EC of soil samples are given in Table (2). EC values of the soil samples studied range from 0.578 to $24.026 \mathrm{dS} \mathrm{m}^{-1}$ for the saturated soil paste extracts, from 0.257 to $10.775 \mathrm{dS} \mathrm{m}^{-1}$ for $\mathrm{SW} 1: 1$ extracts, from 0.028 to $6.983 \mathrm{dS} \mathrm{m}^{-1}$ for SW1:2.5 extracts, and from 0.039 to $3.349 \mathrm{dS} \mathrm{m}^{-1}$ for $\mathrm{SW} 1: 5$ extracts. As suggested by USDA (1954), Rhoades (1982) and Sonmez et al.(2008), the EC of soil extracts is decreased by increasing the soil to water ratios due to dilution effects.

Mean ion concentrations and electrical conductivities for saturated paste extracts were almost two fold greater than that of the SW1:1 extracts, about four fold greater than that of the SW1:2.5 extracts, and approximately eight fold greater than that of the SW1:5 extracts (Table 2). In other words, when soil to water ratios are increased about two fold, approximately two fold diluted values are measured. These results were also reported by Zhang et al. (2005) and Sonmez et al.(2008) who obtained two fold dilution when comparing the saturated paste result with $(1: 1)$ soil to water ratio.

The measured EC values of the saturated paste extracts $\left(\mathrm{EC}_{\mathrm{sp}}\right)$ versus those of different soil to water ratios (SW1:1, SW1:2.5 and $\mathrm{SW1:5)}$ for SANWD, CALMD and CLYLA soils are presented in Fig. 1, 2 and 3, respectively. Regression relationships revealed that the slopes of the regression lines increase with increasing the soil to water ratios reflecting the dilution effects. The linear regression relationships were found to be the best fit model to the obtained data for all soil to water ratios and soil types. The dashed lines in these figures represent the $95 \%$ confidence level intervals for the regression lines. The resulted regression equations with and without intercept are given in Table (3). High coefficients of determination of the regression equations range from 0.934 to 0.995 . There are no drastic changes in either the slopes or the coefficients of determination of the regression equations when the intercept is excluded (Table 3). The high coefficients of determination obtained indicate highly significant relationships between saturated paste extracts and different soil to water ratios. These results are close to those reported by Shirokova et al.(2000), Zhang et al. (2005), Ozcan et al. (2006) and Sonmez et al.(2008).

The slopes of the regression equations of SANWD, CALMD and CLYLA soils are 2.424, 1.968 and 2.028, respectively, for SW1:1 extracts. These values are very close to those reported by Sonmez et al. (2008) who obtained slopes $2.72,2.15$, and 2.03 for sandy, loamy, and clay textured soils, respectively, for (1:1) soil to water ratios. While The slopes of the regression equations of coarse, medium and fine soils given by Franzen (2003) were 3.01, 3.01, and 2.96, respectively, for the same soil to water ratios. These differences in results can be attributed to several soil characteristics such as texture, type and content of clay minerals, organic matter and calcium carbonate contents. An explanation to the high slope values for SANWD soils is that in the coarse textured soils soluble salts are easily washed to the solution due to the low surface area of soil particles, absence of layered-negatively charged clay minerals and hence low adsorption capacity of ions. The opposite behavior can be expected from the soils with high clay and organic matter contents (Franzen, 2003; Sonmez et al.; 2008). This can justify higher values of slopes of regression equations for the SANWD soils compared to the CLYLA soils (Table 3).

For SW1:2.5, regression slopes with intercept are 4.172, 2.948 and 3.701 for SANWD, CALMD and CLYLA soils, respectively (Table 3 ). These slopes are slightly increased to 4.394, 3.164 and 3.861, respectively when intercepts are omitted. SW1:5 extracts show the same trend but with almost doubled values due to the dilution effect. Regression lines with intercepts have slopes 7.412, 7.767 and 7.118 for SANWD, CALMD and CLYLA soils, respectively. These slopes are increased to 7.522, 7.762 and 7.412 for SANWD, CALMD and CLYLA soils, respectively when intercepts are included. Slightly higher slopes were reported by Sonmez et al. (2008) who obtained slopes of (1:2.5) soil to water ratio regression lines 4.34, 3.84 and 3.68 without intercepts and 4.41, 3.96 and 3.75 with intercepts for sandy, loamy and clay soils, respectively. They also obtained slopes of (1:5) soil to water ratio regression lines $8.22,7.58$ and 7.63 without intercepts and 7.98, 7.62 and 7.19 with intercepts for sandy, loamy and clay soils, respectively. On the other hand, Ozcan et al. (2006) reported a lower regression slope of 5.97 with intercept for the (1:5) soil to water ratio of sandy soils but they did not take soil textural classes into consideration.

Regression equations with coefficients of determination of soluble ions concentrations with and without intercept along with the EC equations are presented in Tables 4, 5 and 6 for SANWD, CALMD and CLYLA soils, respectively. Generally, slopes of the regression lines increase with increasing soil to water ratios for all ions but with different magnitudes among ions. 


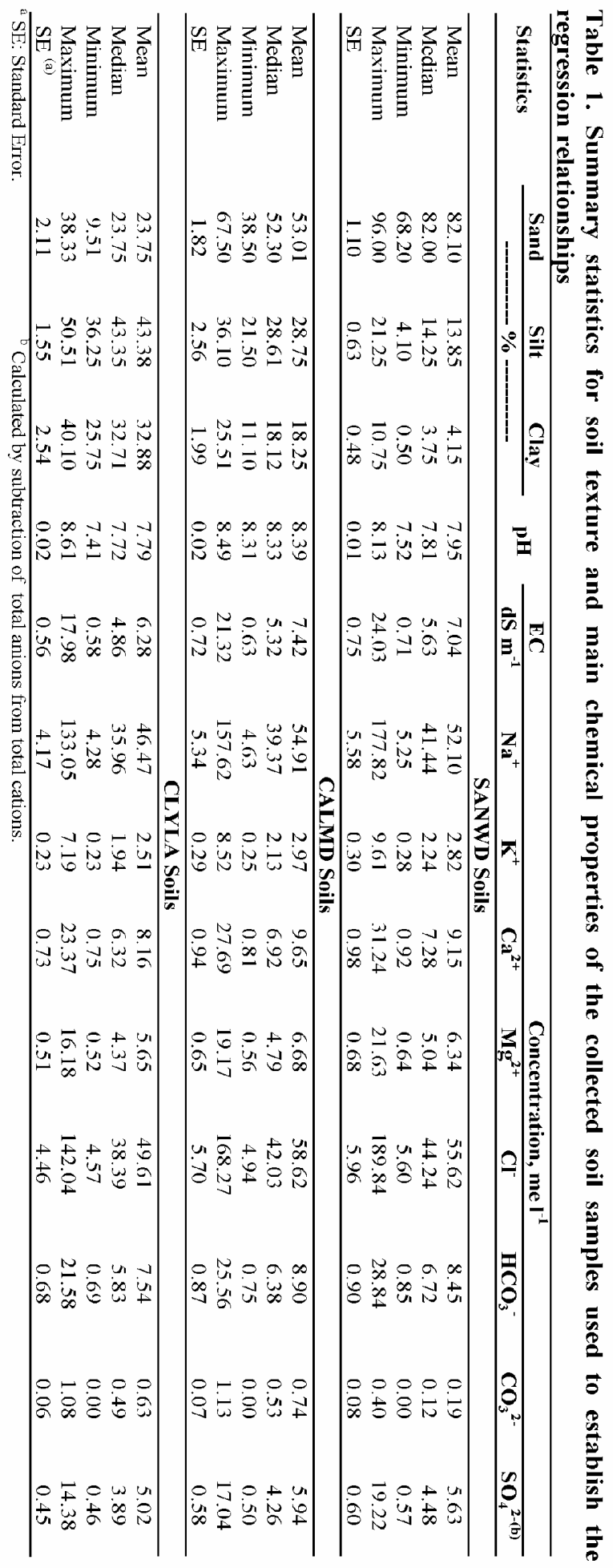


Table 2. Descriptive statistics for EC ( $\left.\mathrm{dS} \mathrm{m}^{-1}\right)$ of saturated soil paste extracts and different soil to water ratios

\begin{tabular}{lcccc}
\hline \multirow{2}{*}{ Parameter } & \multicolumn{3}{c}{ Extracts } \\
\cline { 2 - 5 } & Soil paste & SW1:1 & SW1:2.5 & SW1:5 \\
\hline Mean & 7.01 & 3.27 & 1.82 & 0.91 \\
Standard Error & 0.68 & 0.32 & 0.20 & 0.09 \\
Median & 4.87 & 2.69 & 1.21 & 0.69 \\
Standard Deviation & 5.91 & 2.75 & 1.73 & 0.79 \\
Sample Variance & 34.97 & 7.57 & 3.01 & 0.62 \\
Kurtosis & 0.28 & 0.48 & 1.27 & 0.52 \\
Skewness & 1.07 & 1.11 & 1.39 & 1.13 \\
Range & 23.45 & 10.52 & 6.96 & 3.31 \\
Minimum & 0.58 & 0.26 & 0.03 & 0.04 \\
Maximum & 24.03 & 10.78 & 6.98 & 3.35 \\
Count & 75 & 75 & 75 & 75 \\
Confidence Level (95.0\%) & 1.36 & 0.63 & 0.39 & 0.18 \\
\hline
\end{tabular}

Table 3. Regression equations and coefficients of determination $\left(\mathrm{r}^{2}\right)$ for $\mathrm{EC}\left(\mathrm{dS} \mathrm{m}^{-1}\right)$ in saturated soil paste extracts $\left(\mathrm{EC}_{\mathrm{sp}}\right)$ versus different soil to water ratios

\begin{tabular}{|c|c|c|c|c|}
\hline \multirow{2}{*}{ Extract } & \multicolumn{2}{|c|}{ Without intercept } & \multicolumn{2}{|c|}{ With intercept } \\
\hline & Equation & $\mathbf{r}^{2}$ & Equation & $\mathbf{r}^{2}$ \\
\hline & \multicolumn{4}{|c|}{ SANWD soils } \\
\hline SW1:1 & $\mathrm{EC}_{\mathrm{sp}}=2.424 \mathrm{x}$ & $0.95^{* * *}$ & $\mathrm{EC}_{\mathrm{sp}}=2.346 \mathrm{x}+0.424$ & $0.96^{* * *}$ \\
\hline SW $1: 2.5$ & $\mathrm{EC}_{\mathrm{sp}}=4.394 \mathrm{y}$ & $0.97^{* * *}$ & $\mathrm{EC}_{\mathrm{sp}}=4.172 \mathrm{x}+0.685$ & $0.98^{* * *}$ \\
\hline \multirow[t]{2}{*}{ SW1:5 } & $\mathrm{EC}_{\mathrm{sp}}=7.522 \mathrm{z}$ & $0.99^{* * *}$ & $\mathrm{EC}_{\mathrm{sp}}=7.412 \mathrm{x}+0.192$ & $0.98^{* * *}$ \\
\hline & \multicolumn{4}{|c|}{ CALMD soils } \\
\hline SW1:1 & $\mathrm{EC}_{\mathrm{sp}}=1.968 \mathrm{x}$ & $0.98^{* * *}$ & $\mathrm{EC}_{\mathrm{sp}}=1.933 \mathrm{x}+0.222$ & $0.97^{* * *}$ \\
\hline SW1:2.5 & $\mathrm{EC}_{\mathrm{sp}}=3.164 \mathrm{y}$ & $0.98^{* * *}$ & $\mathrm{EC}_{\mathrm{sp}}=2.948 \mathrm{y}+0.927$ & $0.96^{* * *}$ \\
\hline \multirow[t]{2}{*}{ SW1:5 } & $\mathrm{EC}_{\mathrm{sp}}=7.762 \mathrm{z}$ & $0.98^{* * *}$ & $\mathrm{EC}_{\mathrm{sp}}=7.676 \mathrm{z}+0.138$ & $0.98^{* * *}$ \\
\hline & \multicolumn{4}{|c|}{ CLYLA soils } \\
\hline SW1:1 & $\mathrm{EC}_{\mathrm{sp}}=2.028 \mathrm{x}$ & $0.98^{* * *}$ & $\mathrm{EC}_{\mathrm{sp}}=2.102 \mathrm{x}+0.354$ & $0.96^{* * *}$ \\
\hline SW $1: 2.5$ & $\mathrm{EC}_{\mathrm{sp}}=3.861 \mathrm{y}$ & $0.97^{* * *}$ & $\mathrm{EC}_{\mathrm{sp}}=3.701 \mathrm{y}+0.420$ & $0.93^{* * *}$ \\
\hline SW1:5 & $\mathrm{EC}_{\mathrm{sp}}=7.412 \mathrm{z}$ & $0.98^{* * *}$ & $\mathrm{EC}_{\mathrm{sp}}=7.118 \mathrm{z}+0.402$ & $0.96^{* * *}$ \\
\hline
\end{tabular}

$\mathrm{x}, \mathrm{y}$ and $\mathrm{z}$ are the values measured in SW1:1, SW1:2.5 and SW1:5 extracts, respectively.

${ }^{*}$ Significant, ${ }^{* *}$ Highly significant, ${ }^{* * *}$ very highly significant, ${ }^{\text {ns }}$ not significant.

The degree of correlation between soluble ions concentration of saturated paste extracts versus different soil to water ratios varies more among different ions than among soil to water ratios. Although $\mathrm{Na}$ and $\mathrm{Cl}$ ions show the highest coefficients of determination (0.92-0.99), $\mathrm{K}$ ion show the lowest coefficients of determination (0.47-0.84), and $\mathrm{Ca}$ and $\mathrm{Mg}$ ions show moderate coefficients of determination in CALMD soils (0.61-0.71), and high values in SANWD and CLYLA soils (0.71-0.98). Slight decrease in the slopes of the regression equations was observed after omitting the intercept for all ions in different soil to water ratios (Tables 4, 5 and 6).

Inspection of the results of EC given in Table (3) and Figs. 1, 2 and 3 shows that the slopes for the SW1:1, SW1:2.5 and SW1:5 extracts are close to 2, 4 and 7.5 , respectively, for the three soil types. This means that the effect of dilution in the different soil to water ratios is superior to the effect of soil type. Therefore, data of the EC for each soil to water ratio were combined for the three soil types to establish

one regression line as shown in Table 7 and Fig. 4. Slopes of the regression lines without intercept of the EC are 2.12, 3.64 and 7.58 for SW1:1, SW1:2.5 and SW1:5, respectively, with slightly higher coefficients of determination than those with intercept (Table 7). Regression lines for soluble ions concentration for combined soils show generally lower coefficients of determination than the EC regression lines. 

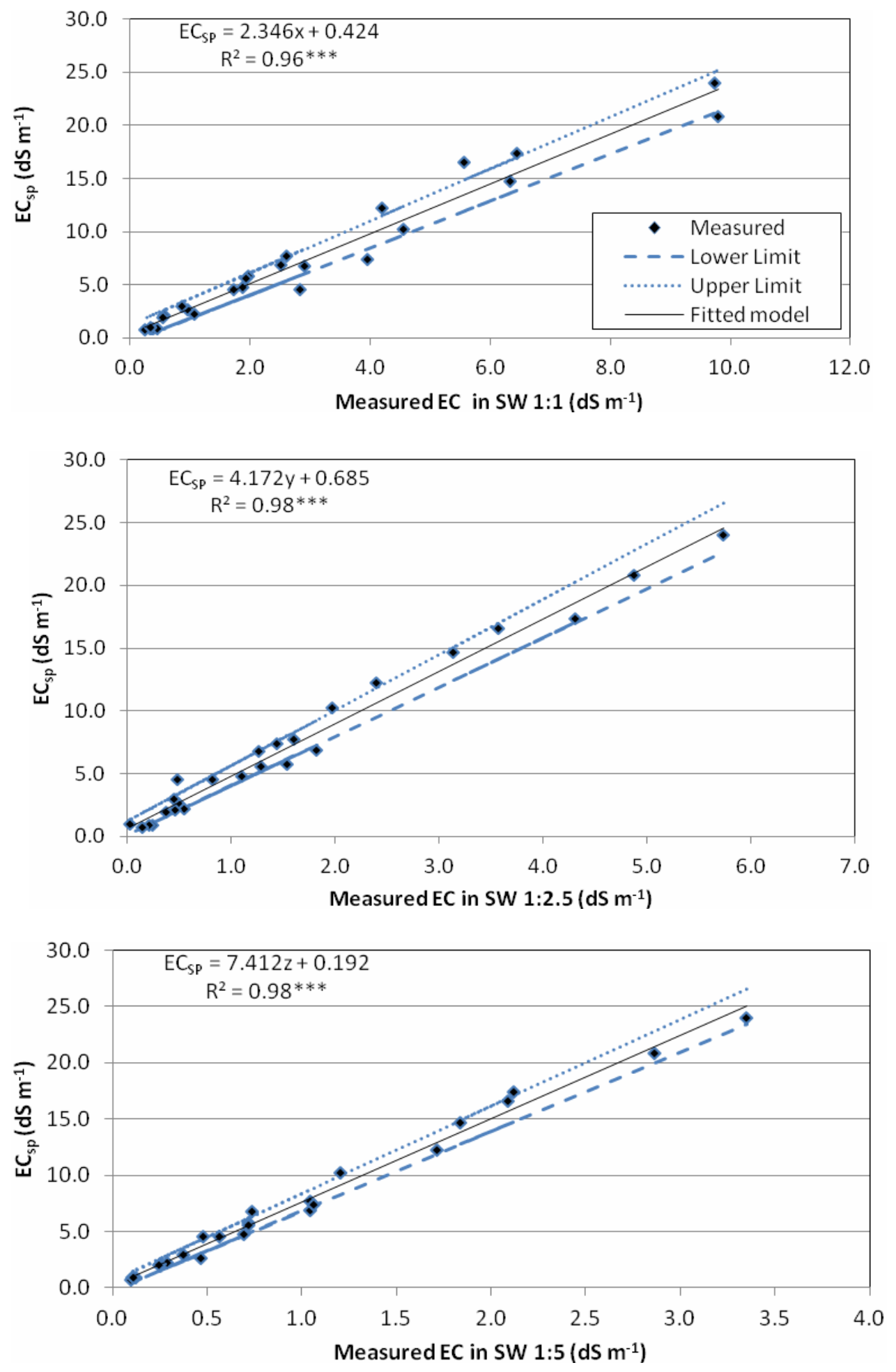

Figure 1. Regression relationships of EC measured in saturated soil paste extracts $\left(E C_{S P}\right)$ versus different soil to water ratios for SANWD soils 

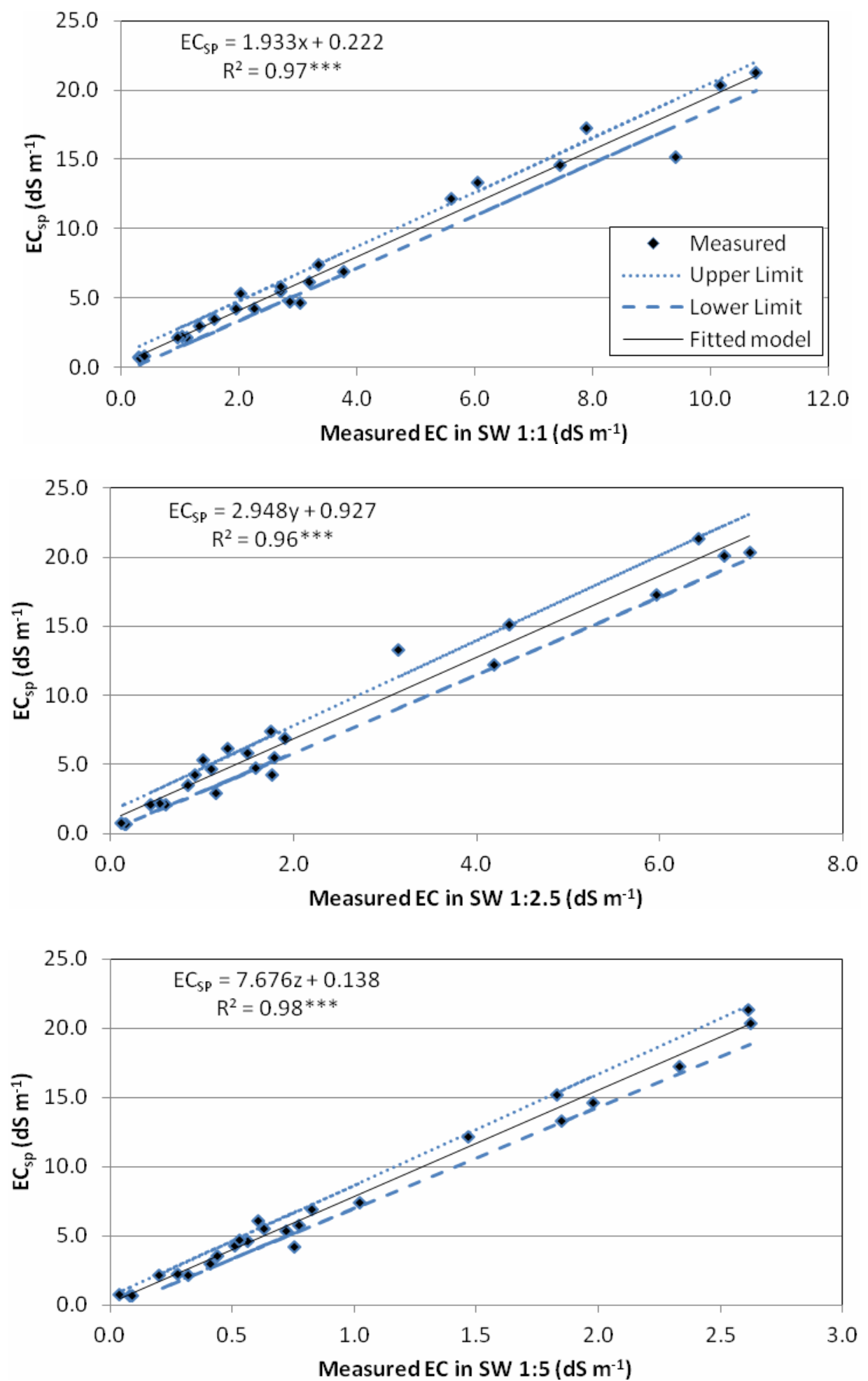

Figure 2. Regression relationships of EC measured in saturated soil paste extracts $\left(\mathrm{EC}_{\mathrm{SP}}\right)$ versus different soil to water ratios for CALMD soils 

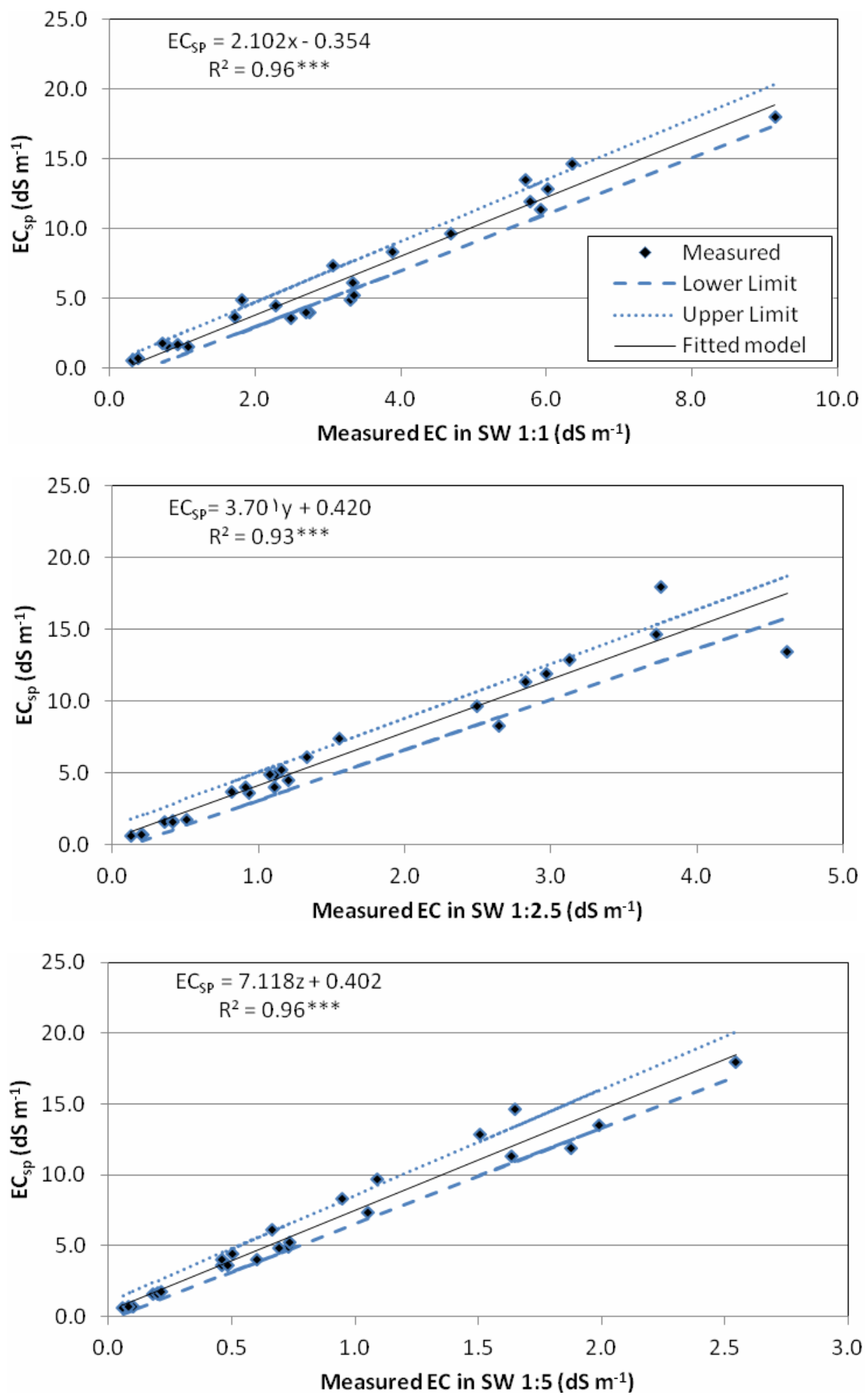

Figure 3. Regression relationships of EC measured in saturated soil paste extracts $\left(\mathrm{EC}_{\mathrm{SP}}\right)$ versus different soil to water ratios for CLYLA soils 
Table 4. Regression equations and coefficients of determination $\left(r^{2}\right)$ for soluble ions concentrations ( $\mathrm{me}^{-1}$ ) of saturated soil paste extracts versus different soil to water ratios for SANWD soils

\begin{tabular}{|c|c|c|c|c|}
\hline \multirow{2}{*}{ Parameter } & \multicolumn{2}{|c|}{ Without intercept } & \multicolumn{2}{|c|}{ With intercept } \\
\hline & Equation & $\mathbf{r}^{2}$ & Equation & $\mathbf{r}^{2}$ \\
\hline \multicolumn{5}{|c|}{ SW 1:1 } \\
\hline $\mathrm{Cl}^{-}$ & $\mathrm{Cl}_{\mathrm{sp}}=3.37 \mathrm{x}$ & $0.95^{* * *}$ & $\mathrm{Cl}_{\mathrm{sp}}=3.99 \mathrm{x}+51.23$ & $0.96^{* * *}$ \\
\hline $\mathrm{K}^{+}$ & $\mathrm{K}_{\mathrm{sp}}=1.29 \mathrm{x}$ & $0.50^{*}$ & $\mathrm{~K}_{\mathrm{sp}}=2.05 \mathrm{x}+0.21$ & $0.47^{\mathrm{ns}}$ \\
\hline $\mathrm{Na}^{+}$ & $\mathrm{Na}_{\mathrm{sp}}=2.52 \mathrm{x}$ & $0.98^{* * *}$ & $\mathrm{Na}_{\mathrm{sp}}=2.71 \mathrm{x}+6.71$ & $0.99^{* * *}$ \\
\hline $\mathrm{Ca}^{2+}$ & $\mathrm{Ca}_{\mathrm{sp}}=3.17 \mathrm{x}$ & $0.82^{* *}$ & $\mathrm{Ca}_{\mathrm{sp}}=4.85 \mathrm{x}+34.01$ & $0.71^{* *}$ \\
\hline $\mathrm{Mg}^{2+}$ & $\mathrm{Mg}_{\mathrm{sp}}=3.98 \mathrm{x}$ & $0.71^{* *}$ & $\mathrm{Mg}_{\mathrm{sp}}=5.12 \mathrm{x}+10.91$ & 0.87 \\
\hline \multicolumn{5}{|c|}{ SW $1: 2.5$} \\
\hline $\mathrm{Cl}^{-}$ & $\mathrm{Cl}_{\mathrm{sp}}=6.07 \mathrm{y}$ & $0.98^{* * *}$ & $\mathrm{Cl}_{\mathrm{sp}}=6.20 \mathrm{y}+6.38$ & $0.99^{* * *}$ \\
\hline $\mathrm{K}^{+}$ & $\mathrm{K}_{\mathrm{sp}}=2.43 \mathrm{y}$ & $0.73^{* *}$ & $\mathrm{~K}_{\mathrm{sp}}=2.23 \mathrm{y}+0.07$ & $0.74^{* *}$ \\
\hline $\mathrm{Na}^{+}$ & $\mathrm{Na}_{\mathrm{sp}}=4.53 \mathrm{y}$ & $0.99^{* * *}$ & $\mathrm{Na}_{\mathrm{sp}}=4.51 \mathrm{y}+0.14$ & $0.99^{* * *}$ \\
\hline $\mathrm{Ca}^{2+}$ & $\mathrm{Ca}_{\mathrm{sp}}=5.22 \mathrm{y}$ & $0.92^{* * *}$ & $\mathrm{Ca}_{\mathrm{sp}}=5.40 \mathrm{y}+0.03$ & $0.96^{* * *}$ \\
\hline $\mathrm{Mg}^{2+}$ & $\mathrm{Mg}_{\mathrm{sp}}=10.61 \mathrm{y}$ & $0.98^{* * *}$ & $\mathrm{Mg}_{\mathrm{sp}}=10.98 \mathrm{y}+6.78$ & $0.98^{* * *}$ \\
\hline \multicolumn{5}{|c|}{ SW $1: 5$} \\
\hline $\mathrm{Cl}^{-}$ & $\mathrm{Cl}_{\mathrm{sp}}=10.34 \mathrm{z}$ & $0.97^{* * *}$ & $\mathrm{Cl}_{\mathrm{sp}}=10.74 \mathrm{z}+13.54$ & $0.99^{* * *}$ \\
\hline $\mathrm{K}^{+}$ & $\mathrm{K}_{\mathrm{sp}}=2.96 \mathrm{z}$ & $0.59^{*}$ & $\mathrm{~K}_{\mathrm{sp}}=2.55 \mathrm{z}+0.11$ & $0.64^{*}$ \\
\hline $\mathrm{Na}^{+}$ & $\mathrm{Na}_{\mathrm{sp}}=8.38 \mathrm{z}$ & $0.98^{* * *}$ & $\mathrm{Na}_{\mathrm{sp}}=8.41 \mathrm{z}+0.52$ & $0.98^{* * *}$ \\
\hline $\mathrm{Ca}^{2+}$ & $\mathrm{Ca}_{\mathrm{sp}}=9.81 \mathrm{z}$ & $0.98^{* * *}$ & $\mathrm{Ca}_{\mathrm{sp}}=10.68 \mathrm{z}+7.39$ & $0.99^{* * *}$ \\
\hline $\mathrm{Mg}^{2+}$ & $\mathrm{Mg}_{\mathrm{sp}}=16.34 \mathrm{z}$ & $0.96^{* * *}$ & $\mathrm{Mg}_{\mathrm{sp}}=18.21 \mathrm{z}+12.11$ & $0.98^{* * *}$ \\
\hline
\end{tabular}

$\mathrm{x}, \mathrm{y}$ and $\mathrm{z}$ are the values measured in SW1:1, SW1:2.5 and SW1:5 extracts, respectively.

Significant, ${ }^{* *}$ Highly significant, ${ }^{* * *}$ very highly significant, ${ }^{\text {ns }}$ not significant.

Table 5. Regression equations and coefficients of determination $\left(r^{2}\right)$ for soluble ions concentrations $\left(\mathrm{me} \mathrm{I}^{-1}\right)$ of saturated soil paste extracts versus different soil to water ratios for CALMD soils

\begin{tabular}{|c|c|c|c|c|}
\hline \multirow[b]{2}{*}{ Parameter } & \multicolumn{2}{|c|}{ Without intercept } & \multicolumn{2}{|c|}{ With intercept } \\
\hline & Equation & $\mathbf{r}^{2}$ & Equation & $\mathbf{r}^{2}$ \\
\hline \multicolumn{5}{|c|}{ SW 1:1 } \\
\hline $\mathrm{Cl}^{-}$ & $\mathrm{Cl}_{\mathrm{sp}}=2.31 \mathrm{x}$ & $0.98^{* * *}$ & $\mathrm{Cl}_{\mathrm{sp}}=2.19 \mathrm{x}+3.10$ & $0.99^{* * *}$ \\
\hline $\mathrm{K}^{+}$ & $\mathrm{K}_{\mathrm{sp}}=1.67 \mathrm{x}$ & $0.52^{*}$ & $\mathrm{~K}_{\mathrm{sp}}=1.49 \mathrm{x}+0.03$ & $0.53^{*}$ \\
\hline $\mathrm{Na}^{+}$ & $\mathrm{Na}_{\mathrm{sp}}=2.02 \mathrm{x}$ & $0.99^{* * *}$ & $\mathrm{Na}_{\mathrm{sp}}=2.02 \mathrm{x}+.05$ & $0.99^{* * *}$ \\
\hline $\mathrm{Ca}^{2+}$ & $\mathrm{Ca}_{\mathrm{sp}}=1.97 \mathrm{x}$ & $0.68^{* *}$ & $\mathrm{Ca}_{\mathrm{sp}}=2.21 \mathrm{x}+4.99$ & $0.70^{*}$ \\
\hline $\mathrm{Mg}^{2+}$ & $\mathrm{Mg}_{\mathrm{sp}}=1.65 \mathrm{x}$ & $0.69^{* *}$ & $\mathrm{Mg}_{\mathrm{sp}}=1.41 \mathrm{x}+9.21$ & $0.71^{* *}$ \\
\hline \multicolumn{5}{|c|}{ SW 1:2.5 } \\
\hline $\mathrm{Cl}^{-}$ & $\mathrm{Cl}_{\mathrm{sp}}=5.18 \mathrm{y}$ & $0.99^{* * *}$ & $\mathrm{Cl}_{\mathrm{sp}}=4.89 \mathrm{y}+6.29$ & $0.99^{* * *}$ \\
\hline $\mathrm{K}^{+}$ & $\mathrm{K}_{\mathrm{sp}}=2.46 \mathrm{y}$ & $0.71^{* *}$ & $\mathrm{~K}_{\mathrm{sp}}=2.11 \mathrm{y}-0.08$ & $0.72^{* *}$ \\
\hline $\mathrm{Na}^{+}$ & $\mathrm{Na}_{\mathrm{sp}}=3.74 \mathrm{y}$ & $0.99^{* * *}$ & $\mathrm{Na}_{\mathrm{sp}}=3.65 \mathrm{y}+3.11$ & $0.99^{* * *}$ \\
\hline $\mathrm{Ca}^{2+}$ & $\mathrm{Ca}_{\mathrm{sp}}=9.65 \mathrm{y}$ & $0.69^{*}$ & $\mathrm{Ca}_{\mathrm{sp}}=4.85 \mathrm{y}+0.81$ & $0.70^{* *}$ \\
\hline $\mathrm{Mg}^{2+}$ & $\mathrm{Mg}_{\mathrm{sp}}=4.71 \mathrm{y}$ & $0.68^{* *}$ & $\mathrm{Mg}_{\mathrm{sp}}=4.84 \mathrm{y}+2.35$ & $0.69^{* *}$ \\
\hline \multicolumn{5}{|c|}{ SW 1:5 } \\
\hline $\mathrm{Cl}^{-}$ & $\mathrm{Cl}_{\mathrm{sp}}=10.54 \mathrm{z}$ & $0.98^{* * *}$ & $\mathrm{Cl}_{\mathrm{sp}}=11.61 \mathrm{z}+0.31$ & $0.99^{* * *}$ \\
\hline $\mathrm{K}^{+}$ & $\mathrm{K}_{\mathrm{sp}}=3.49 \mathrm{z}$ & $0.51^{*}$ & $\mathrm{~K}_{\mathrm{sp}}=2.51 \mathrm{z}-1.1$ & $0.52^{*}$ \\
\hline $\mathrm{Na}^{+}$ & $\mathrm{Na}_{\mathrm{sp}}=7.69 \mathrm{z}$ & $0.99^{* * *}$ & $\mathrm{Na}_{\mathrm{sp}}=8.05 \mathrm{z}-0.91$ & $0.99^{* * *}$ \\
\hline $\mathrm{Ca}^{2+}$ & $\mathrm{Ca}_{\mathrm{sp}}=15.99 \mathrm{z}$ & $0.61^{* *}$ & $\mathrm{Ca}_{\mathrm{sp}}=19.65 \mathrm{z}-4.65$ & $0.63^{* *}$ \\
\hline $\mathrm{Mg}^{2+}$ & $\mathrm{Mg}_{\mathrm{sp}}=10.03 \mathrm{z}$ & $0.62^{* *}$ & $\mathrm{Mg}_{\mathrm{sp}}=9.85 \mathrm{z}+-15.32$ & $0.68^{* *}$ \\
\hline
\end{tabular}

$\mathrm{x}, \mathrm{y}$ and $\mathrm{z}$ are the values measured in SW1:1, SW1:2.5 and SW1:5 extracts, respectively.

* Significant, ${ }^{* *}$ Highly significant, ${ }^{* * *}$ very highly significant, ${ }^{\mathrm{ns}}$ not significant. 

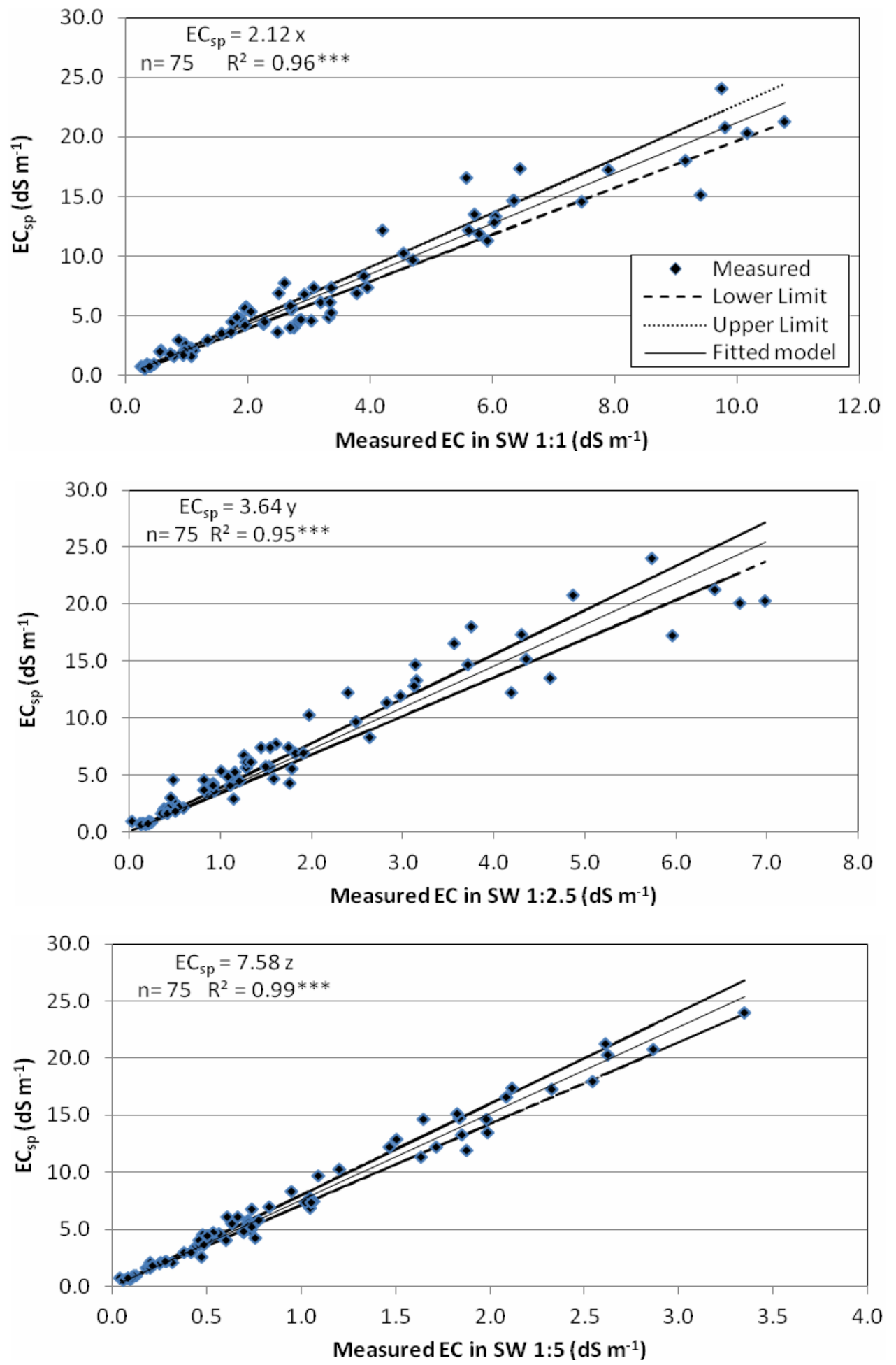

Figure 4. Regression relationships of EC measured in saturated soil paste extracts $\left(\mathrm{EC}_{\mathrm{SP}}\right)$ versus different soil to water ratios for combined soil types 
Table 6. Regression equations and coefficients of determination $\left(r^{2}\right)$ for soluble ions concentrations ( $\mathrm{me} \mathrm{l}^{-1}$ ) of saturated soil paste extracts versus different soil to water ratios for CLYLA soils

\begin{tabular}{|c|c|c|c|c|}
\hline \multirow{2}{*}{ Parameter } & \multicolumn{2}{|c|}{ Without intercept } & \multicolumn{2}{|c|}{ With intercept } \\
\hline & Equation & $\mathbf{r}^{2}$ & Equation & $\mathbf{r}^{2}$ \\
\hline & \multicolumn{4}{|c|}{ SW 1:1 } \\
\hline $\mathrm{Cl}^{-}$ & $\mathrm{Cl}_{\mathrm{sp}}=2.01 \mathrm{x}$ & $0.96^{* * *}$ & $\mathrm{Cl}_{\mathrm{sp}}=2.11 \mathrm{x}-10.51$ & $0.97^{* * * *}$ \\
\hline $\mathrm{K}^{+}$ & $\mathrm{K}_{\mathrm{sp}}=1.54 \mathrm{x}$ & $0.65^{* *}$ & $\mathrm{~K}_{\mathrm{sp}}=1.42 \mathrm{x}+0.01$ & $0.66^{*}$ \\
\hline $\mathrm{Na}^{+}$ & $\mathrm{Na}_{\mathrm{sp}}=2.38 \mathrm{x}$ & $0.92^{* * *}$ & $\mathrm{Na}_{\mathrm{sp}}=2.11 \mathrm{x}-0.22$ & $0.93^{* * *}$ \\
\hline $\mathrm{Ca}^{2+}$ & $\mathrm{Ca}_{\mathrm{sp}}=2.21 \mathrm{x}$ & $0.98^{* * *}$ & $\mathrm{Ca}_{\mathrm{sp}}=2.61 \mathrm{x}-0.02$ & $0.98^{* * *}$ \\
\hline \multirow[t]{2}{*}{$\mathrm{Mg}^{2+}$} & $\mathrm{Mg}_{\mathrm{sp}}=1.89 \mathrm{x}$ & $0.95^{* * *}$ & $\mathrm{Mg}_{\mathrm{sp}}=2.35 \mathrm{x}-5.99$ & $0.96^{* * *}$ \\
\hline & \multicolumn{4}{|c|}{ SW 1:2.5 } \\
\hline $\mathrm{Cl}^{-}$ & $\mathrm{Cl}_{\mathrm{sp}}=4.31 \mathrm{y}$ & $0.98^{* * *}$ & $\mathrm{Cl}_{\mathrm{sp}}=4.35 \mathrm{y}-13.11$ & $0.99^{* * *}$ \\
\hline $\mathrm{K}^{+}$ & $\mathrm{K}_{\mathrm{sp}}=3.44 \mathrm{y}$ & $0.73^{* *}$ & $\mathrm{~K}_{\mathrm{sp}}=3.48 \mathrm{y}-0.09$ & $0.84^{* *}$ \\
\hline $\mathrm{Na}^{+}$ & $\mathrm{Na}_{\mathrm{sp}}=4.34 \mathrm{y}$ & $0.99^{* * *}$ & $\mathrm{Na}_{\mathrm{sp}}=4.52 \mathrm{y}-1.99$ & $0.99^{* * *}$ \\
\hline $\mathrm{Ca}^{2+}$ & $\mathrm{Ca}_{\mathrm{sp}}=6.61 \mathrm{y}$ & $0.99^{* * *}$ & $\mathrm{Ca}_{\mathrm{sp}}=6.71 \mathrm{y}-0.99$ & $0.99^{* * *}$ \\
\hline \multirow[t]{2}{*}{$\mathrm{Mg}^{2+}$} & $\mathrm{Mg}_{\mathrm{sp}}=4.68 \mathrm{y}$ & $0.96^{* * *}$ & $\mathrm{Mg}_{\mathrm{sp}}=5.11 \mathrm{y}-8.71$ & $0.97^{* * *}$ \\
\hline & \multicolumn{4}{|c|}{ SW $1: 5$} \\
\hline $\mathrm{Cl}^{-}$ & $\mathrm{Cl}_{\mathrm{sp}}=7.69 \mathrm{z}$ & $0.97^{* * *}$ & $\mathrm{Cl}_{\mathrm{sp}}=7.98 \mathrm{z}+1.01$ & $0.99^{* * *}$ \\
\hline $\mathrm{K}^{+}$ & $\mathrm{K}_{\mathrm{sp}}=3.25 \mathrm{z}$ & $0.71^{* *}$ & $\mathrm{~K}_{\mathrm{sp}}^{\mathrm{sp}}=3.32 \mathrm{z}-0.19$ & $0.74^{* *}$ \\
\hline $\mathrm{Na}^{+}$ & $\mathrm{Na}_{\mathrm{sp}}=6.76 \mathrm{z}$ & $0.99^{* * *}$ & $\mathrm{Na}_{\mathrm{sp}}=7.89 \mathrm{z}-2.04$ & $0.99^{* * *}$ \\
\hline $\mathrm{Ca}^{2+}$ & $\mathrm{Ca}_{\mathrm{sp}}=11.21 \mathrm{z}$ & $0.95^{* * *}$ & $\mathrm{Ca}_{\mathrm{sp}}=12.79 \mathrm{z}-5.84$ & $0.96^{* * *}$ \\
\hline $\mathrm{Mg}^{2+}$ & $\mathrm{Mg}_{\mathrm{sp}}=7.54 \mathrm{z}$ & $0.93^{* * *}$ & $\mathrm{Mg}_{\mathrm{sp}}=8.87 \mathrm{z}-10.98$ & $0.95^{* * *}$ \\
\hline
\end{tabular}

$\mathrm{x}, \mathrm{y}$ and $\mathrm{z}$ are the values measured in SW1:1, SW1:2.5 and SW1:5 extracts, respectively.

${ }^{*}$ Significant, ${ }^{* *}$ Highly significant, ${ }^{* * *}$ very highly significant, ${ }^{\text {ns }}$ not significant.

Table 7. Regression equations and coefficients of determination $\left(r^{2}\right)$ for $\operatorname{EC}\left(\mathrm{dS} \mathrm{m}^{-1}\right)$ and soluble ions concentrations ( $\mathrm{me}^{-1}$ ) of saturated soil paste extracts versus different soil to water ratios for combined soil types

\begin{tabular}{|c|c|c|c|c|}
\hline \multirow{3}{*}{ Parameter } & \multicolumn{2}{|c|}{ Without intercept } & \multicolumn{2}{|c|}{ With intercept } \\
\hline & Equation & $\mathbf{r}^{2}$ & Equation & $\mathbf{r}^{2}$ \\
\hline & \multicolumn{4}{|c|}{ SW 1:1 } \\
\hline $\mathrm{EC}, \mathrm{dS} \mathrm{m}^{-1}$ & $\mathrm{EC}_{\mathrm{sp}}=2.12$ & $0.97^{* * *}$ & $\mathrm{EC}_{\mathrm{sp}}=2.09 \mathrm{x}+0.18$ & $0.94^{\text {*** }}$ \\
\hline $\mathrm{Cl}^{-}, \mathrm{me} \mathrm{l}^{-1}$ & $\mathrm{Cl}_{\mathrm{sp}}=2.28 \mathrm{x}$ & $0.91^{* *}$ & $\mathrm{Cl}_{\mathrm{sp}}=2.24 \mathrm{x}+1.13$ & $0.92^{* *}$ \\
\hline $\mathrm{K}^{+}, \mathrm{me} \mathrm{l}^{-1}$ & $\mathrm{~K}_{\mathrm{sp}}=1.52 \mathrm{x}$ & $0.57^{*}$ & $\mathrm{~K}_{\mathrm{sp}}=1.39 \mathrm{x}+0.01$ & $0.56^{*}$ \\
\hline $\mathrm{Na}^{+}, \mathrm{me} \mathrm{l}^{-1}$ & $\mathrm{Na}_{\mathrm{sp}}=2.31 \mathrm{x}$ & $0.94^{* * *}$ & $\mathrm{Na}_{\mathrm{sp}}=2.33 \mathrm{x}-1.21$ & $0.93^{* * *}$ \\
\hline $\mathrm{Ca}^{2+}, \mathrm{me} \mathrm{l}^{-1}$ & $\mathrm{Ca}_{\mathrm{sp}}=2.12 \mathrm{x}$ & $0.84^{* *}$ & $\mathrm{Ca}_{\mathrm{sp}}=2.53 \mathrm{x}-2.34$ & $0.83^{* *}$ \\
\hline \multirow[t]{2}{*}{$\mathrm{Mg}^{2+}, \mathrm{me} \mathrm{l}^{-1}$} & $\mathrm{Mg}_{\mathrm{sp}}=1.70 \mathrm{x}$ & $0.74^{* *}$ & $\mathrm{Mg}_{\mathrm{sp}}=1.67 \mathrm{x}+10.84$ & $0.73^{* *}$ \\
\hline & \multicolumn{4}{|c|}{ SW $1: 2.5$} \\
\hline $\mathrm{EC}, \mathrm{dS} \mathrm{m}^{-1}$ & $\mathrm{EC}_{\mathrm{sp}}=3.64 \mathrm{y}$ & $0.90^{* * * *}$ & $\mathrm{EC}_{\mathrm{sp}}=3.35 \mathrm{y}+0.10$ & $0.92^{* * *}$ \\
\hline $\mathrm{Cl}^{-}, \mathrm{me} \mathrm{l}^{-1}$ & $\mathrm{Cl}_{\mathrm{sp}}=5.11 \mathrm{y}$ & $0.96^{* * *}$ & $\mathrm{Cl}_{\mathrm{sp}}=5.22 \mathrm{y}-2.99$ & $0.96^{* * *}$ \\
\hline $\mathrm{K}^{+}, \mathrm{me} \mathrm{l}^{-1}$ & $\mathrm{~K}_{\mathrm{sp}}=2.52 \mathrm{y}$ & $0.79^{* *}$ & $\mathrm{~K}_{\mathrm{sp}}=2.37 \mathrm{y}+0.03$ & $0.80^{* *}$ \\
\hline $\mathrm{Na}^{+}, \mathrm{me} \mathrm{l}^{-1}$ & $\mathrm{Na}_{\mathrm{sp}}=4.13 \mathrm{y}$ & $0.99^{* * * *}$ & $\mathrm{Na}_{\mathrm{sp}}=4.19 \mathrm{y}+0.1$ & $0.99^{* * *}$ \\
\hline $\mathrm{Ca}^{2+}, \mathrm{me} \mathrm{l}^{-1}$ & $\mathrm{Ca}_{\mathrm{sp}}=8.97 \mathrm{y}$ & $0.91^{* * *}$ & $\mathrm{Ca}_{\mathrm{sp}}=11.05 \mathrm{y}-7.88$ & $0.95^{* * *}$ \\
\hline \multirow[t]{2}{*}{$\mathrm{Mg}^{2+}, \mathrm{me} \mathrm{l}^{-1}$} & $\mathrm{Mg}_{\mathrm{sp}}=4.79 \mathrm{y}$ & $0.93^{* * *}$ & $\mathrm{Mg}_{\mathrm{sp}}=5.07 \mathrm{y}-2.31$ & $0.94^{* * *}$ \\
\hline & \multicolumn{4}{|c|}{ SW 1:5 } \\
\hline $\mathrm{EC}, \mathrm{dS} \mathrm{m}^{-1}$ & $\mathrm{EC}_{\mathrm{sp}}=7.58 \mathrm{y}$ & $0.9^{9^{* * *}}$ & $\mathrm{EC}_{\mathrm{sp}}=7.43 \mathrm{y}+0.23$ & $0.98^{* * *}$ \\
\hline $\mathrm{Cl}^{-}, \mathrm{me} \mathrm{l}^{-1}$ & $\mathrm{Cl}_{\mathrm{sp}}=11.02 \mathrm{z}$ & $0.96^{* * *}$ & $\mathrm{Cl}_{\mathrm{sp}}=11.21 \mathrm{z}-10.51$ & $0.96^{* * *}$ \\
\hline $\mathrm{K}^{+}, \mathrm{me} \mathrm{l}^{-1}$ & $\mathrm{~K}_{\mathrm{sp}}=2.98 \mathrm{z}$ & $0.55^{*}$ & $\mathrm{~K}_{\mathrm{sp}}=2.68 \mathrm{z}+0.03$ & $0.58^{*}$ \\
\hline $\mathrm{Na}^{+}, \mathrm{me} \mathrm{l}^{-1}$ & $\mathrm{Na}_{\mathrm{sp}}=8.31 \mathrm{z}$ & $0.99^{* * *}$ & $\mathrm{Na}_{\mathrm{sp}}=8.11 \mathrm{z}-0.51$ & $0.99^{* * *}$ \\
\hline $\mathrm{Ca}^{2+}, \mathrm{me} \mathrm{l}^{-1}$ & $\mathrm{Ca}_{\mathrm{sp}}=16.11 \mathrm{z}$ & 0.90 & $\mathrm{Ca}_{\mathrm{sp}}=18.95 \mathrm{z}-16.31$ & $0.92^{* * * *}$ \\
\hline $\mathrm{Mg}^{2+}, \mathrm{me} \mathrm{l}^{-1}$ & $\mathrm{Mg}_{\mathrm{sp}}=9.27 \mathrm{z}$ & $0.91^{* * *}$ & $\mathrm{Mg}_{\mathrm{sp}}=10.10 \mathrm{z}-7.87$ & $0.91^{* *}$ \\
\hline
\end{tabular}

$\mathrm{x}, \mathrm{y}$ and $\mathrm{z}$ are the values measured in SW1:1, SW1:2.5 and SW1:5 extracts, respectively.

${ }^{*}$ Significant, ${ }^{* *}$ Highly significant, ${ }^{* * *}$ very highly significant, ${ }^{\text {ns }}$ not significant. 
While $\mathrm{K}$ ion has the lowest coefficients of determination, $0.55-0.80, \mathrm{Na}$ and $\mathrm{Cl}$ ions have the highest coefficients of determination, 0.91-0.96, and $\mathrm{Ca}$ and $\mathrm{Mg}$ ions have moderate to high coefficients of determination, 0.73-0.93 (Table 7). Snomez et al. (2008) reported combined regression slopes without intercepts of $2.11,4.00$ and 7.57 for $(1: 1),(1: 2.5)$ and $(1: 5)$ soil to water ratios, respectively.

\section{CONCLUSION}

This study showed that electrical conductivity and soluble ions concentrations of saturated soil paste extracts and (1:1), (1:2.5) and (1:5) soil to water ratios are obviously influenced by soil types. Soil specific and combined regression equations of the electrical conductivity, anions and cations concentrations versus those of different soil to water ratios were derived. The use of the either soil specific or combined equations is dependent on the level of data precision required, where soil specific equations can give more precise results. The three soil to water ratios studied proved to be precisely capable of estimating saturated paste extract electrical conductivity and ion concentrations. The conversion of $(1: 1),(1: 2.5)$ and (1:5) soil to water ratios results to saturated paste extract equivalents has potentially great benefits. These benefits include minimum cost and less time consumption while maintaining a high accuracy and precision levels. The use of the $(1: 2.5)$ soil suspensions prepared for electrical conductivity and soluble ions concentrations measurements has more specific benefit as it can be also used in soil $\mathrm{pH}$ measurements, minimizing time and costs associated with soil salinity studies.

\section{REFERENCES}

Ayers, R.S., and D.W. Westcot. 1989. Water quality for agriculture. FAO Irrigation and Drainage Paper 29 Rev. 1. Rome.

Day, P.R. 1982. Particle Fractionation and Particle Size Analysis. SSSA, Madison, Wisconsin, p. 545. USA.

Costat, 2004. CoStat: Statistical Analysis Package Ver. 6.303. CoHort Software. CA, USA.

Franzen, D. 2003. Managing Saline Soils in North Dakota. North Dakota State University Extension Service, Fargo. Available online at http://www.ag. ndsu.edu/pubs/plantsci/ soilfert/sf1087-1.htm (verified on October 10, 2006).

Hogg, T.J., and J.L. Henry. 1984. Comparison of 1:1 and 1:2 suspensions and extracts with the saturation extract in estimating salinity in Saskatchewan soils. Can. J. Soil Sci. 64:669-704.
Jackson, M. C. 1967. Soil Chemical Analysis. Prentice Hall of India Private Limited, New Delhi, USA.

Ozcan, H., H. Ekinci, Y. Yigini, and O. Yuksel. 2006. Comparison of four soil salinity extraction methods. Proceedings of 18th International Soil Meeting on "Soil Sustaining Life on Earth, Managing Soil and Technology", May 22-26, 2006, Sanliurfa, Turkey, p. 697-703.

Nassem, M.G., M.A. Hussein, and K.A. Abdl-Gader. 2008. Comparative study on salinity measurements in soils of the north western coastal region of Egypt. Alex. Sci. Exch. J. 29:45-54

Page, A.L., R.H. Miller and D.R. Keeney. 1982. Methods of Soil Analysis. Part 1\&2, $2^{\text {nd }}$ Ed. Agronomy Society of America, Madison, WI.

Pitman, M., and A. Lauchli. 2002. Global impacts of salinity and agricultural ecosystems. In: Lauchli, A., Lüttge, U. (Eds.), Salinity: Environmental Plants Molecules. Kluwer Academics, pp. -20 .

Qadir, M., A. Ghafoor, and G. Murtaza. 2000. Amelioration strategies for saline soils. Land Degrad. and Develop. 11, 501-521.

Rhoades, J.D. 1982. Soluble salts, In: Page, A.L. (Ed.), Methods of Soil Analysis, Part 2, Second Edition, American Society of Agronomy, Inc., Madison, WI, USA, p. 167-179. Agronomy Monograph No 9.

Rhoades, J.D., and J. Loveday. 1990. Salinity in irrigated agriculture. In: Stewert, B.A., Nielsen, D.R. (Eds.), Irrigation of Agricultural Crops. ASAE, Madison, WI, p. 1089-1142. Agronomy Monograph No 30.

Shama, M.A., S.A.M. Moussa, and N.I.A. El Fadel. 2016. Salicylic acid efficacy on resistance of garlic plants (Allium sativum, L.) to water salinity stress on growth, yield and its quality. Alex. Sci. Exch. J. 37:165-174

Shaw, R. 1994. Estimation of the electrical conductivity of saturation extracts from the electrical conductivity of 1:5 soil : water suspensions and various soil properties. Research Project Report Series Q094025. Department of Primary Industry. Queensland, Australia.

Shirokova, Y., I. Forkusta, and N. Sharafutdinova. 2000. Use of electrical conductivity instead of soluble salts for soil salinity monitoring in Central Asia. Drain Syst, 14, 199205.

Sonmez, S., D. Buyuktas, F. Okturen, and S. Citak. 2008. Assessment of different soil to water ratios (1:1, 1:2.5, 1:5) in soil salinity studies. Geoderma 144: 361-369

USDA, 1954. Diagnoses and improvement of saline and alkali soils. Agric. Handbook No. 60. USSL, Riverside, CA, USA.

Zhang, H., J.L. Schroder, J.J. Pittman, J.J. Wang, and M.E. Payton. 2005. Soil salinity using saturated paste and 1:1 soil to water extract. Soil Sci. Soc. Am. J. 69, 1146-1151. 


\section{الملذص العري}

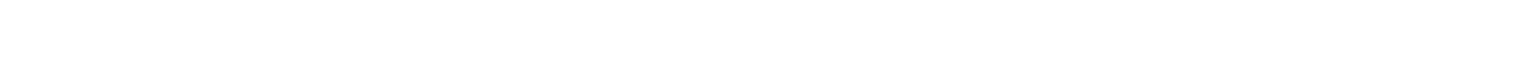

رمزي مبسي رزق هدية

ا :0 لكل نوع تربه ـة وك ذذك لأن _واع الت _رب مجتمع ـة

.Combined

وقد أثبتت الدرلسة نجاح عملية هسلب ق يم التوص ليل

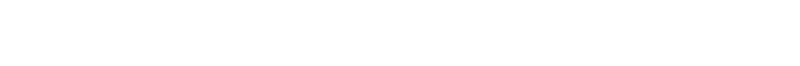

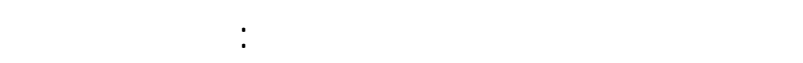

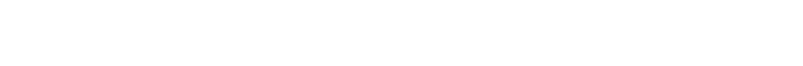

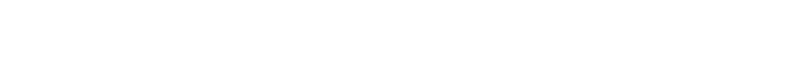

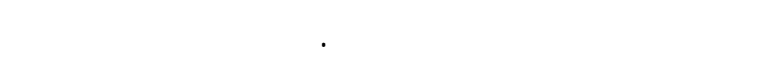
V,OSlopes

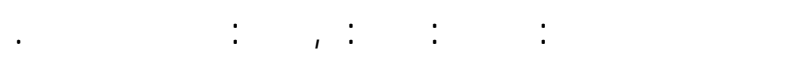

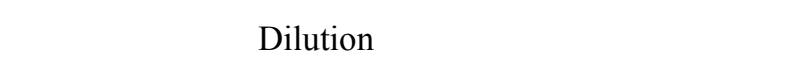
الذوبلن في التربة بزيادة نسبة الماء إل م التربه ـة ـ ويع ـد

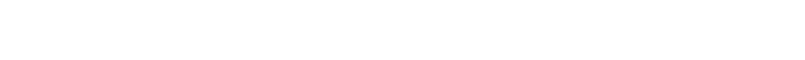

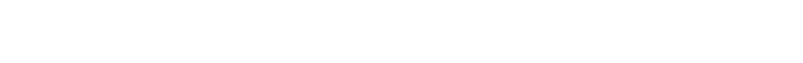
الذائبة لعجينة التربة المشبعة ذات فوائد واعدة ف مي نقلي لل الجهد والوقت والتكالي Labor, Time and Cost اللازم الية للحصول على مستخلص عجينة التربة المشبعة. وقد أوصت

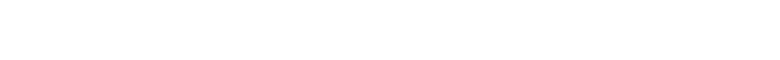
Sفي حالة الحلجة لققديرات أكثر دقة لخصائص عجينة التربة المشبعة، مقارنة بالمعادلات الت مي تجمع أنواع الترب الثلاثة لل مستخلص.
ع الة ما تستخدم مستخلصك عجينة التربة الم شبعة Saturated Soil Paste إله الماء Soil to Water Ratios في درلسلت ملوحة الترب ـة وعمليت معالجة الترب المتأثرة بالأملاح. وقد لجريت هذه

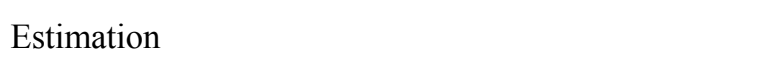

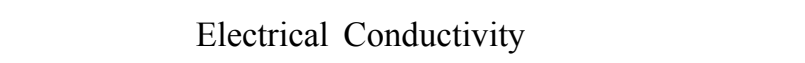

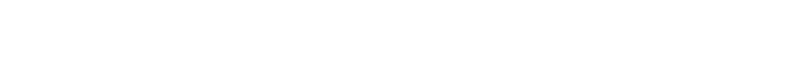

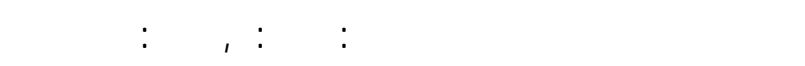
التربة:الماء. م تجمبع خهس وعثرون عينة تربةسطحية مفككة من كل نوع تربة لتمل الترب الرملي ـة والجيري ـة والطيني ـة

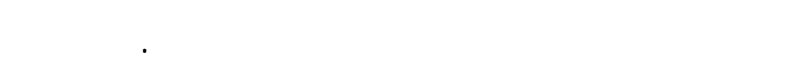
قيلست التوصيل الكهربي وتركي -زات الأيوذ ـات الذائب ــة $\left(\mathrm{Na}^{+}, \mathrm{K}^{+}, \mathrm{Ca}^{2+}\right.$ and $\mathrm{Mg}^{2+}, \mathrm{Cl}^{-}, \mathrm{CO}_{3}{ }^{2-}$, and في مستخلصك هذه العينت. مم ققويم مع ادلات $\mathrm{HCO}_{3}{ }^{-}$)

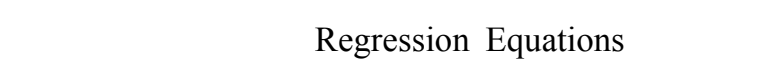
Determination Coefficients

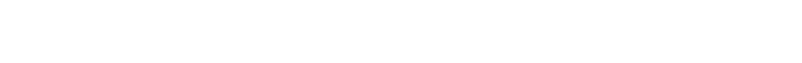

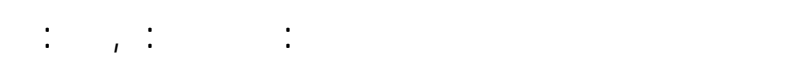

